[Agr. Biol. Chem., Vol. 26, No. 7. p. 424 433, 1962]

\title{
Studies on Q-Enzyme of Rice Plant
}

\author{
Part X.* Purification and Physico-chemical Properties of Q-Enzyme** \\ By Ikuo Igaue \\ Department of Agricultural Chemistry, Faculty of Agriculture, \\ Niigata University, Niigata \\ Received March 7, 1962
}

\begin{abstract}
Purification of Q-enzyme prepared from the extract of rice seed at the milky stage employing precipitation by lead acetate, fractionation by ammonium sulfate and chromatography on hydroxylapatite was carried out. The highly purified preparation of Q-enzyme was nearly homogeneous in electrophoresis, chromatography and solubility, and was nearly free from amylase, maltase, isoamylase, phosphorylase and phosphatase activities. Some of the physico-chemical and enzymic properties of the preparation were also investigated.
\end{abstract}

Since Q-enzyme was isolated by Haworth et al.1) from potato juice, its purification has been studied by many workers on various sources.

As for the purification of potato Q-enzyme, Bourne et al. ${ }^{2)}$ have reported a method by kaolin treatment and ammonium sulfate fractionation. Thereafter, Barker et al. ${ }^{3 \sim 5)}$ have obtained a preparation substantially free from amylases and fatty acids by using a modified method involving precipitation as a lead complex, while, Gilbert and Patrick ${ }^{6,7)}$ have prepared potato Q-enzyme in crystalline form by ethanol-citrate fractionation at low temperature. Further improvements of the methods for purification have been developed by Baum \& Gilbert ${ }^{8)}$ and Peat et al. ${ }^{9)}$

\footnotetext{
* Biochemical Studies of Rice Starch. Part XXI.

** Presented at the 13th Meeting of the Symposia of Enzyme Chemistry, Tokyo, July 15, 1961.

1) W.N. Haworth, S. Peat and E.J. Bourne, Nature, 154, 236 (1944).

2) E. J. Bourne and S. Peat, J. Chem. Soc., 1945, 877.

3) S.A. Barker, E.J. Bourne and S. Peat, ibid., 1949, 1705.

4) S.A. Barker, E.J. Bourne and S. Peat, ibid., 1949, 1712.

5) S.A. Barker, E.J. Bourne, I.A. Wilkinson and S. Peat, ibid., 1950,

6) G.A. Gilbert and A.D. Patrick, Nature, 165, 573 (1950).

7) G.A. Gilbert and A.D. Patrick, Biochem. J., 51, 181 (1952).

8) H. Baum and G.A. Gilbert, Nature, 171, 983 (1953).

9) S. Peat, J.R. Turvey and G. Jones, J. Chem. Soc., 1959, 1540.
} 84.
Q-enzyme of pulses, Polytomella coeca, green gram, corn and others have been partially purified in a similar manner.

As described above, we may credit the main achievement on the purification of Q-enzyme to Gilbert et al., but the properties of the crystalline preparation obtained by them have not yet been made clear.

Few reports appeared on the purification of Q-enzyme of rice plant. Recently, Nakamura et al.10) have reported the partial purification of Q-enzyme in rice seed of waxy race at the perfect ripe stage. Our preliminary examinations $^{11)}$ with the Q-enzyme fraction prepared from rice seed at the milky stage by lead acetate precipitation and ammonium sulfate fractionation have shown that chromatography on hydroxylapatite is effective in separating Q-enzyme from other impurities.

Its further purification yielded a Q-enzyme preparation which appeared to be homogeneous by electrophoretic analysis.

The present report deals with the purifica-

10) Y. Nakamura, T. Shimomura and J. Yamada, J. Agr. Chem. Soc. Japan, 35, 587 (1961).

11) I. Igaue, ibid., 34, 1028 (1960). 
tion of Q-enzyme of rice plant and with the informations obtained during the process.

\section{MATERIALS AND METHODS}

Rice Plants. Rice plants of starchy race, such as variety Koshiziwase, Nihonkai and Yomohikari, were the materials mainly used. Rice seed was sampled at the milky stage (8 to 12 days after flowering), the highest activity of $Q$-enzyme during ripening.

Substrates. Amylose: Rice amylose which was used as the substrate of Q-enzyme throughout this study, was prepared from the defatted starch of variety Koshiziwase by the method of $\operatorname{Schoch}^{12)}$, and was recrystallized 5 times from water saturated with n-butanol.

Amylopectin: Rice amylopectin was isolated from the first mother liquor after removal of amylose fraction and purified by precipitation with methanol.

Beta-Limit Dextrin: Amylopectin $\beta$-limit dextrin was prepared by the prolonged action of crystalline $\beta$-amylase on rice amylopectin, followed by dialysis to be removed from maltose and inorganic substance and by precipitations twice with ethanol. The $\beta$ amylase was a preparation from sweet potato ${ }^{13)}$ recrystallized three times.

Maltose: Commercial maltose, Difco Laboratories, U.S.A., was used without further purification.

Glucose-1-Phosphate: Crystalline dipotassium salt was prepared by the enzymic method of Nakamura ${ }^{14)}$, followed by recrystallization twice from ethanol and acetone, respectively.

Beta-Glycerophosphate: Commercial sodium $\beta$ glycerophosphate, Kanto Chemicals Co., Japan (extra pure), was used without further purification.

Determination of Enzyme Activity. Q-Enzyme Activity: Q-Enzyme activity was determined by the iodine-staining method as reported previously ${ }^{15}$.

The components of standard digest were as follows: $5 \mathrm{ml}$ of $0.2 \%$ amylose solution, $3 \mathrm{ml}$ of $0.2 \mathrm{M}$ citrate buffer, $\mathrm{pH} 6.7,1 \mathrm{ml}$ of Q-enzyme solution and $1 \mathrm{ml}$ of distilled water (total volume $10 \mathrm{ml}$ ). The amylose solution was prepared as follows: $200 \mathrm{mg}$ (dry weight) of amylose was dissolved in $2 \mathrm{ml}$ of $2.5 \mathrm{~N}$ sodium hydroxide solution and diluted with water to about $50 \mathrm{ml}$. After heating at $80^{\circ} \mathrm{C}$ for 10 minutes, the

12) T.J. Schoch, J. Am. Chem. Soc., 64, 2957 (1942)

13) A.K. Balls, M.K. Walden and R.R. Thompson, J. Biol. Chem., 1 73, 9 (1948).

14) M. Nakamura, J. Agr. Chem. Soc. Japan, 26, 260 (1952).

15) I. Igaue, ibid., 36, 110 (1962). solution was cooled, neutralized with diluted hydrochloric acid and made up with water to $100 \mathrm{ml}$. The digest solution was incubated at $27^{\circ} \mathrm{C}$.

One $\mathrm{ml}$ aliquots (equivalent to $1 \mathrm{mg}$ of amylose) were removed at intervals and stained with $1 \mathrm{ml}$ of $0.2 \%$ iodine solution $(0.2 \mathrm{~g}$ of iodine and $2 \mathrm{~g}$ potassium iodide $/ 100 \mathrm{ml}$ ) in a final volume of $25 \mathrm{ml}$. The optical densities were measured in $5 \mathrm{~mm}$ cuvettes using Hirama photoelectric colorimeter fitted with a $655 \mathrm{~m}_{\mu}$ filter. On unit of Q-enzyme activity was defined as the amount of enzyme causing a decrease of $1 \%$ in the optical density of amylose-iodine complex in the digest solution per minute under the above conditions, as reported previously ${ }^{16)}$.

As separated runs, $2 \mathrm{ml}$ aliquots of the digest solution were subjected to Somogyi determination of reducing sugar ${ }^{17}$. The reducing sugar liberated by the action of the enzyme on amylose was determined as the apparent conversion into maltose.

Amylase Activity: The test procedure for amylase activity was essentially the same as that reported previously ${ }^{18)}$. One $\mathrm{ml}$ of the enzyme solution was added at $40^{\circ} \mathrm{C}$ to a mixture of $5 \mathrm{ml}$ of $0.2 \%$ amylose solution and $3 \mathrm{ml}$ of $0.2 \mathrm{M}$ acetate buffer, $\mathrm{pH} 5.5$, and the mixture was made up to $10 \mathrm{ml}$ with distilled water. The digest solution was incubated at $40^{\circ} \mathrm{C}$ and then $2 \mathrm{ml}$ aliquots were taken to be used for determining the reducing sugar by the method of Somogyi; the degree of hydrolysis was calculated in terms of percentage of maltose formed from the theoretical maltose value of amylose. On the other hand, amylopectin $\beta$-limit dextrin in place of amylose in the above digest solution was used as the substrate, and the color reduction of iodine complex of amylopectin $\beta$-limit dextrin was determined by the iodinestaining method described above.

Maltase Activity: The composition of the digest solution was almost the same as that reported previously ${ }^{19)}$. Five $\mathrm{ml}$ of $0.2 \%$ maltose solution, $3 \mathrm{ml}$ of $0.2 \mathrm{M}$ acetate buffer, $\mathrm{pH} 4.4,1 \mathrm{ml}$ of enzyme solution and $1 \mathrm{ml}$ of distilled water were mixed together to make the total volume of $10 \mathrm{ml}$ and incubated at $40^{\circ} \mathrm{C}$.

The glucose formed was determined by the method of Somogyi as described above and the degree of

16) I. Igaue, J. Agr. Chem. Soc. Japan, 34, 1032 (1960)

17) M. Somogyi, J. Biol. Chem., 160, 61 (1945).

18) I. Igaue, S. Mazima and F. Kurasawa, J. Agr. Chem. Soc. Japan, 34, 253 (1960).

19) I. Igaue, S. Higashi and F. Kurasawa, ibid., 34, 258 (1960). 
conversion of maltose to glucose was calculated in percentage.

Isoamylase Activity: The determination of isoamylase activity was made as reported previously ${ }^{20}$. The test was carried out at $40^{\circ} \mathrm{C}$ on the digest solution containing $5 \mathrm{ml}$ of $0.5 \%$ amylopectin, $3 \mathrm{ml}$ of $0.2 \mathrm{M}$ acetate buffer, $\mathrm{pH} 5.5,1 \mathrm{ml}$ of enzyme solution and $1 \mathrm{ml}$ of distilled water, in a total volume of $10 \mathrm{ml}$. One ml samples were taken out at intervals, and the color increment of amylopectin-iodine complex was determined as described above.

Phosphorylase Activity: Phosphorylase activity was determined under the same conditions reported previously $^{21)}$. A solution consisting of $0.5 \mathrm{ml}$ of $5 \%$ soluble starch, $1 \mathrm{ml}$ of $0.2 \mathrm{M}$ citrate buffer, $\mathrm{pH} 6.7$, $0.5 \mathrm{ml}$ of $0.35 \mathrm{M}$ sodium fluoride and $0.5 \mathrm{ml}$ of enzyme solution was brought to $37^{\circ} \mathrm{C}$ and then $1 \mathrm{ml}$ of $0.1 \mathrm{M}$ dipotassium glucose-1-phosphate was added (total volume of $3.5 \mathrm{ml}$ ). At intervals, $0.5 \mathrm{ml}$ samples were taken out and the test for liberated inorganic phosphate was made by the method of Nakamura ${ }^{14)}$.

Phosphatase Activity: The test of phosphatase activity was carried out by the same procedure as for phosphorylase activity, using sodium $\beta$-glycerophosphate or dipotassium glucose-1-phosphate as substrate, excluding soluble starch and sodium fluoride which were used in the test solution for phosphorylase. The digest solution was incubated at $\mathrm{pH} 4.8$ and $37^{\circ} \mathrm{C}$.

Determination of Protein. Protein nitrogen was determined by a micro-Kjeldahl method. As for the determination of protein concentration on chromatography, the method of Folin-ciocalteu modified by Lowry et al. ${ }^{22)}$ was used.

\section{EXPERIMENTAL AND RESULTS}

Purification of Q-Enzyme from Rice Seed at the Milky Stage.

I) Preparation of Original Extract: One and a half $\mathrm{kg}$ (wet weight) of rice seed at the milky stage were soaked for twenty minutes in $0.5 \%$ sodium hydrosulphite solution. The seeds were drained, washed, pounded with a small amount of distilled water and pressed. The turbid green juice was adjusted with $0.05 \mathrm{~N}$ sodium hydroxide to $\mathrm{pH} 7.2$ with vigorous stirring and was centrifuged (3,000 r.p.m.,

20) F. Kurasawa, T. Hayakawa and I. Igaue, J. Agr. Chem. Soc. Japan, 34, 183 (1960).

21) F. Kurasawa, I. Igaue, T. Hayakawa and H. Ôgami, ibid., 33, 393 (1959).

22) O.H. Lowry, N.A. Rosebrough, A.L. Farr and R.J. Randall, J. Biol. Chem., 193, 265 (1951). for ten minutes) to remove starch and other precipitated materials.

II) Treatment by lead Acetate Solution: To 11 of the supernatant, $300 \mathrm{ml}$ of lead acetate solution, $\mathrm{pH} 7.2^{3)}$, was added with stirring, and the green lead-protein precipitate was obtained by centrifugation (3,000 r.p.m., for twenty minutes). The precipitate was stirred with $300 \mathrm{ml}$ of $0.2 \mathrm{~N}$ sodium hydrogen carbonate for ten minutes, and a stream of carbon dioxide was then passed through the suspension for 2.5 minutes. The insoluble residue removed by centrifugation (3,000 r.p.m., for twenty minutes) was discarded.

III) Ammonium Sulfate Fractionation: Solid ammonium sulfate $(18 \mathrm{~g})$ was added to $100 \mathrm{ml}$ of the supernatant which was maintained at $\mathrm{pH} 7.0$ by addition of dilute aqueous ammonia.

The precipitate was collected by filtration and dissolved in $100 \mathrm{ml}$ of distilled water. The ammonium sulfate precipitation was repeated twice.

All these operations were performed in a cold room.

IV) Freeze-drying: The precipitate was dissolved in $50 \mathrm{ml}$ of $0.2 \mathrm{M}$ sodium phosphate buffer, $\mathrm{pH}$ 7.0. The solution was frozen in an acetone-carbon dioxide mixture and was dried in vacuo, $0.05 \sim 0.01 \mathrm{mmHg}$.

V) First Chromatography by Hydroxylapatite: As previously reported ${ }^{11)}$, the author found that $Q$. enzyme adsorbed by hydroxylapatite at low concen. trations of sodium phosphate buffer, $\mathrm{pH}$ 6.8, can be eluted quantitatively with $0.2 \mathrm{M}$ concentration of the same buffer, giving reproducible chromatographic pattern. Further purification was achieved as follows. The freeze-dried material was dissolved in $20 \mathrm{ml}$ of distilled water and was dialyzed with stirring against three changes of $0.05 \mathrm{M}$ sodium phosphate buffer, $\mathrm{pH}$ 6.8 , for thirty hours in a cold room.

The resulting precipitate was removed by centrifugation. The whole dialyzed enzyme solution was applied to a column $16 \times 160 \mathrm{~mm}$ of hydroxylapatite, which was previously equilibrated with $0.05 \mathrm{~m}$ sodium phosphate buffer of $\mathrm{pH}$ 6.8. The stepwise elution with increasing concentrations of sodium phosphate buffer was applied at a flow rate of about $30 \mathrm{ml}$ per hour, and $5 \mathrm{ml}$ fractions were collected. The chromatographic operations were performed in a room at $10 \sim 15^{\circ} \mathrm{C}$.

As shown in Fig. 1, the fraction with Q-enzyme activity appeared at $0.2 \mathrm{M}$ concentration. The $Q$. 


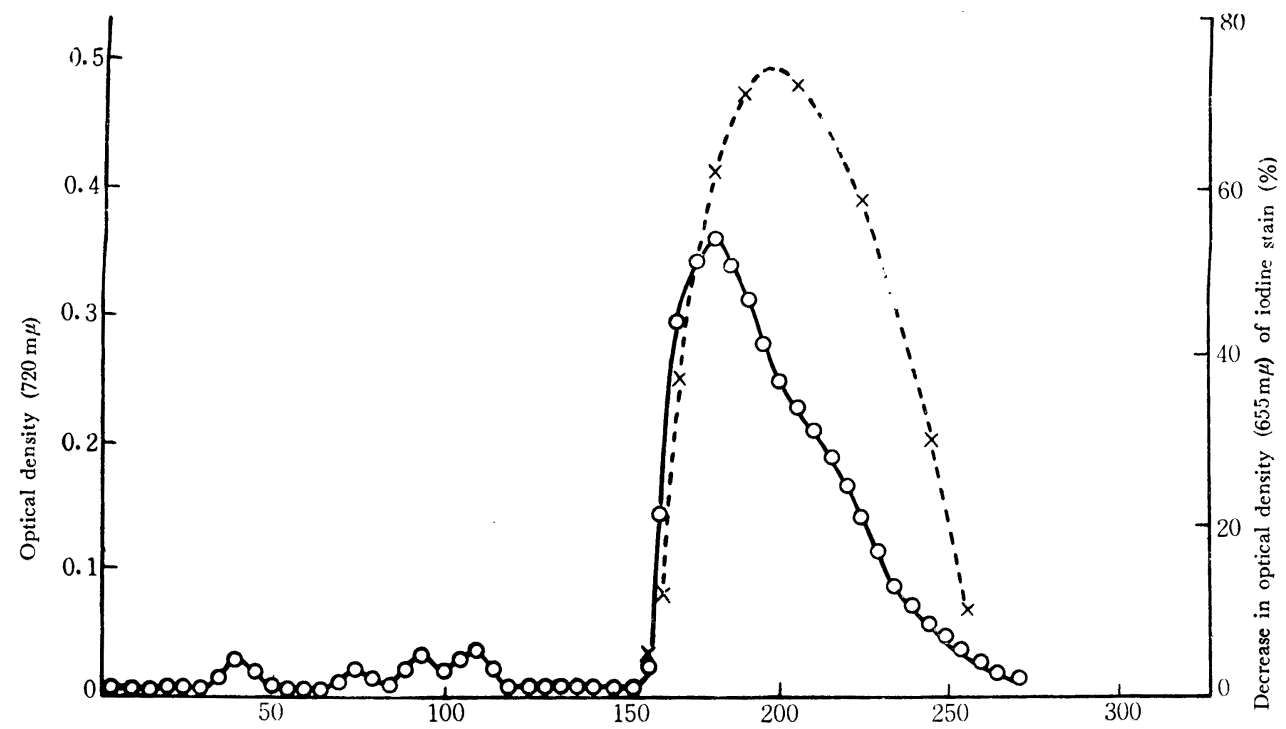

Eluate $(\mathrm{ml})$

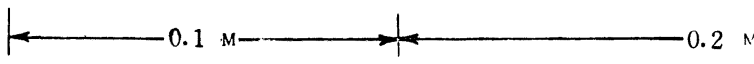

Sodium phosphate buffer concn., $\mathrm{pH} 6.8$

FIG. 1. Chromatography of the Freeze-dried Q-Enzyme Preparation (Enzyme IV). Column, $16 \times 160 \mathrm{~mm}$.

- Optical density $(720 \mathrm{~m} \mu)$ as a measure of protein concn (Lowry method)

-.- - Q-Enzyme activity as percentage decrease in optical density $(655 \mathrm{~m} \mu)$ of iodine stain.

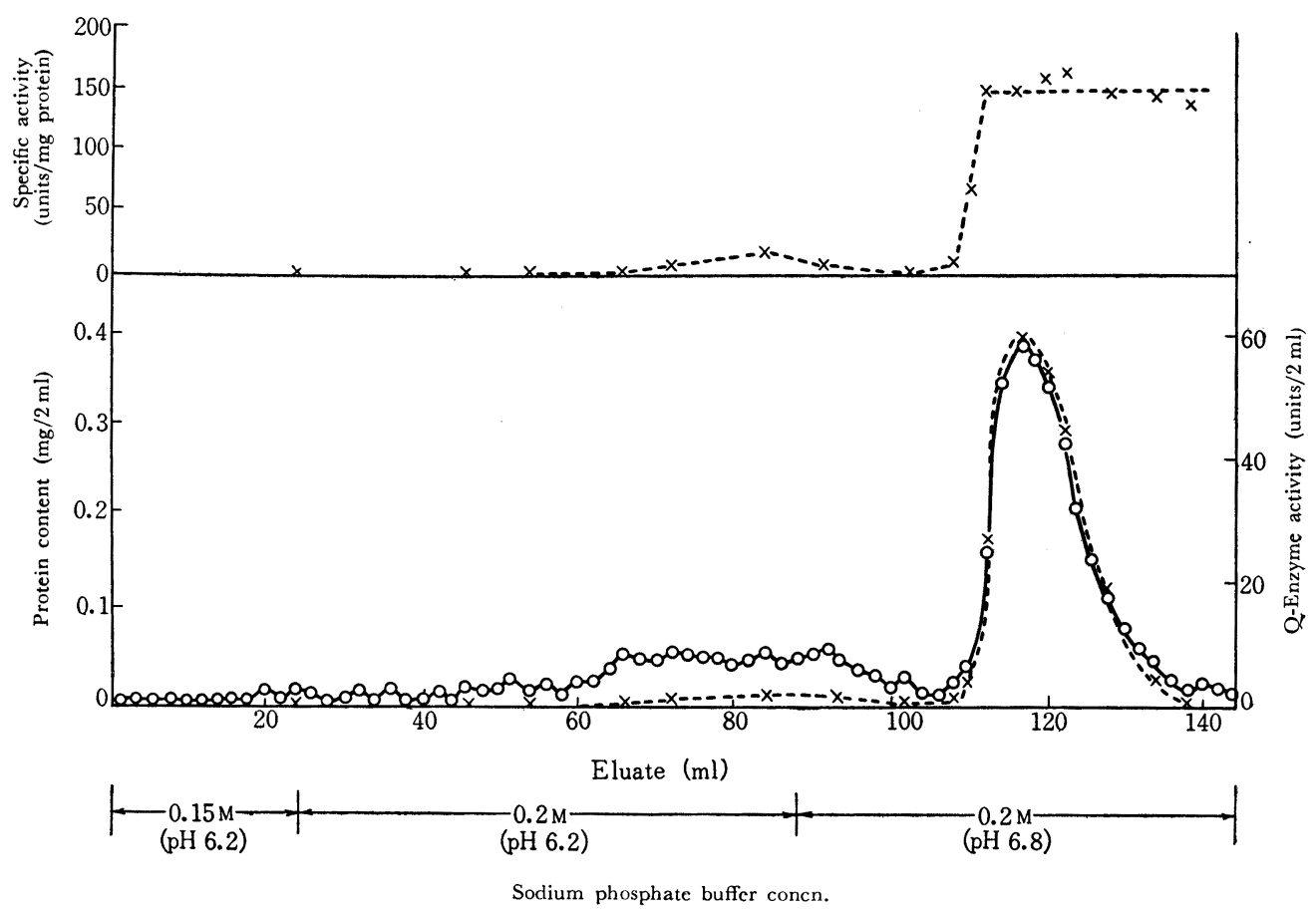

FIG. 2. Separation of Q-Enzyme by Chromatography on Hydroxylapatite.

Column, $12 \times 150 \mathrm{~mm}$. - - - Protein content (Lowry method); --. $\times$--- Q-Enzyme activity. 
enzyme fractions exclusive of those with low specific activity were pooled and precipitated by ammonium sulfate saturation.

VI) Second Chromatography by Hydroxylapatite: As revealed by chromatographic pattern in Fig. 1, the distributions of protein and the enzyme activity in each fraction are not always coincident with each other. Namely, the peak of Q-enzyme activity appears a little later than the protein peak. It may be con- sidered that the protein fraction eluted earlier is the impurity with no activity against substrate. Further attempts to remove this impurity from the Q-enzyme fraction were performed as follows. Preliminary experiments ${ }^{11}$ ) have indicated that $\mathrm{Q}$-enzyme activity was scarely recovered from the hydroxyl. apatite column with $0.2 \mathrm{M}$ sodium phosphate buffer of $\mathrm{pH}$ 6.0. Whereas, by the chromatography with $0.2 \mathrm{M}$ concentration of buffer, $\mathrm{pH} 6.2$, almost all
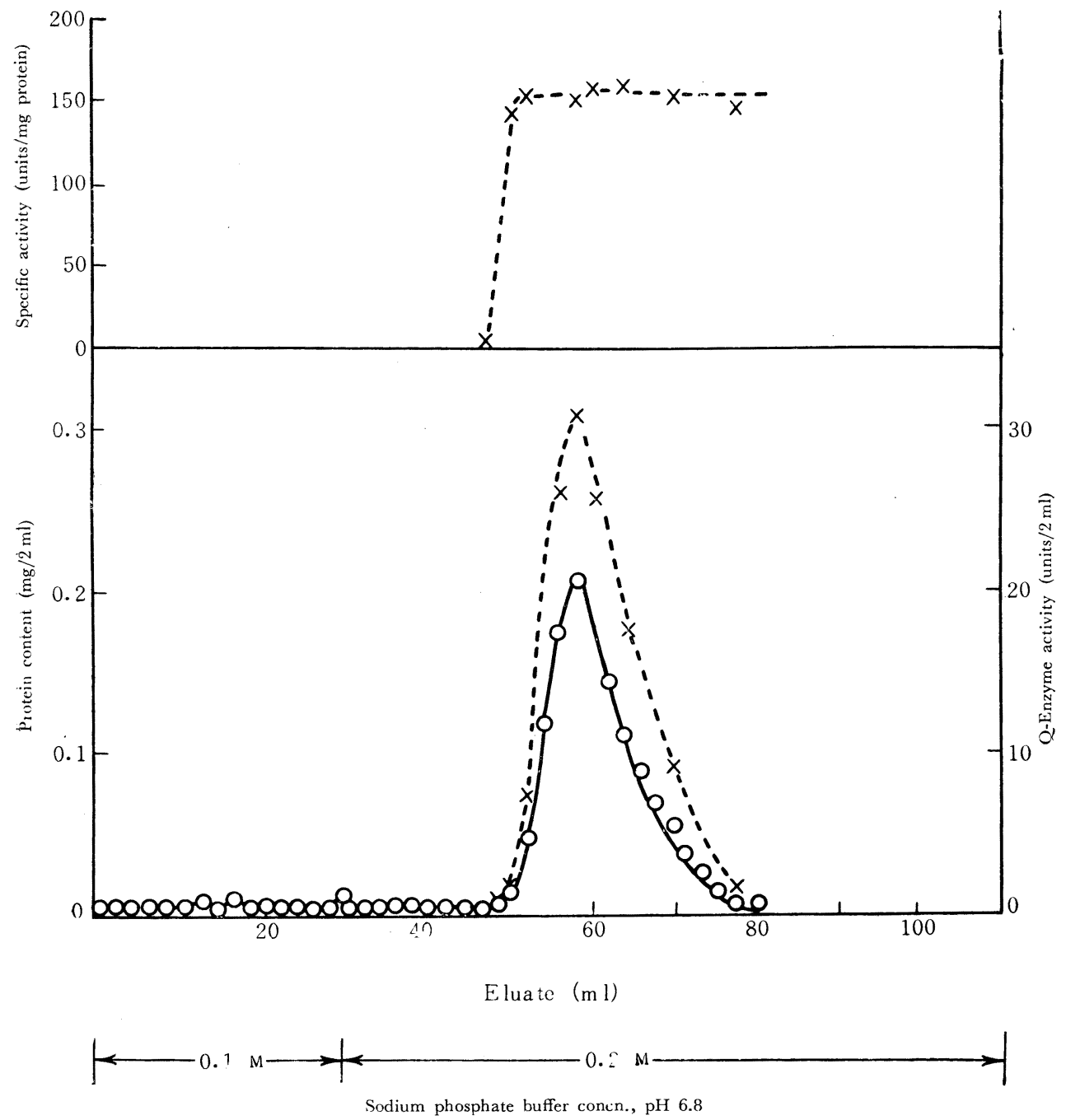

FIG. 3. Rechromatography of the Separated Q-Enzyme Fraction (Enzyme VI). Column, $12 \times 130 \mathrm{~mm}$.

- Protein content (Lowry method)

---X--- Q-Enzyme activity 
impurity and a small amount of Q-enzyme activity were obtained by the following elution with the same concentration of $\mathrm{pH} 6.8$. Thus, the whole of the precipitate obtained by the first chromatography was dissolved in $0.05 \mathrm{M}$ sodium phosphate buffer of pH 6.2 and was dialyzed against the same buffer.

The dialyzed enzyme solution was chromatographed on a column of $12 \times 150 \mathrm{~mm}$ with a flow rate of about $20 \mathrm{ml}$ per hour and $2 \mathrm{ml}$ fractions were collected. The column was stepwise eluted with $0.2 \mathrm{M}$ buffer of $\mathrm{pH}$ 6.2, and was followed by the same concentration of $\mathrm{pH}$ 6.8. As shown in Fig. 2, a major amount of Q-enzyme activity appeared at $0.2 \mathrm{M}$ concentration of buffer, $\mathrm{pH}$ 6.8. Since the impurity was removed by these procedures, the small loss of Q-enzyme activity, as may be seen in Table I, was not disadvantageous. The peak of $Q$-enzyme activity in the main fraction was fairly coincident with the protein peak, and the specific activity in each fraction was nearly constant. By this chromatographic procedure, the specific activity of Q-enzyme fraction rose more than 2-folds that of the first chromatographic preparation, and $77 \%$ of the starting activity was recovered.

When Q-enzyme fraction in this step was rechromatographed by the same procedure, a single symmetrical curve was obtained at the same concentration of buffer, as shown in Fig. 3. The Q-enzyme fractions (main fractions) were pooled and precipitated by ammonium sulfate saturation.

The precipitate was freeze-dried in $25 \mathrm{ml}$ of $0.2 \mathrm{M}$ citrate buffer, $\mathrm{pH} 7.0$ by the same procedure as in step IV and was stored in a cold room. In Table I the recovery data at each step in the purification procedure were summarized. In the steps before step III, it was difficult to determine the significant Q-enzyme activity to be compared, owing to the considerable interference by the contaminating enzymes.

Therefore, the recovery data in the steps after step III was described in the table.

TABle I. ACTIVITIES AND YIELDS OF Q-EnZyME AT EACH STEP OF PURIFICATION

$\begin{array}{llrrrr}\text { Step } & \begin{array}{l}\text { Purification } \\ \text { procedure }\end{array} & \begin{array}{c}\text { Volume } \\ \mathrm{ml}\end{array} & \begin{array}{c}\text { Units/ } \\ \mathrm{ml}\end{array} & \begin{array}{c}\text { Units/mg } \\ \text { protein }\end{array} & \begin{array}{c}\text { Yield } \\ \%\end{array} \\ \text { III } & \begin{array}{l}\text { Ammonium sul- } \\ \text { fate fractionation }\end{array} & 50 & 12.2 & 8.7 & 100 \\ \text { IV } & \text { Freeze-drying } & 28 & 19.7 & 9.5 & 90 \\ \text { V } & \text { 1st. chromatography } & 100 & 4.8 & 65.2 & 78 \\ \text { VI } & \text { 2nd. chromatography } & 25 & 14.9 & 155.0 & 61\end{array}$

Electrophoresis of Q-Enzyme Preparations at Various Steps of Purification.

The enzyme preparations, enzyme IV, V and VI obtained by the purification procedures summarized in Table I were subjected to electrophoretic experiments.

Each enzyme solution was dialyzed for twenty four hours with stirring in a cold room against phosphate buffer of ionic strength 0.1 at $\mathrm{pH} 7.8$, making the protein concentration of $1 \sim 1.35 \%$. The measurements were made in a Tiselius apparatus of Hitachi Model HTD-1 with current of $6 \mathrm{~mA}$ at $3 \sim 7^{\circ} \mathrm{C}$. From the patterns in Fig. $4 \mathrm{~b}$, it was found that enzyme $\mathrm{V}$ was composed of two components, as expected from the chromatographic behavior. The electrophoretic

(c)

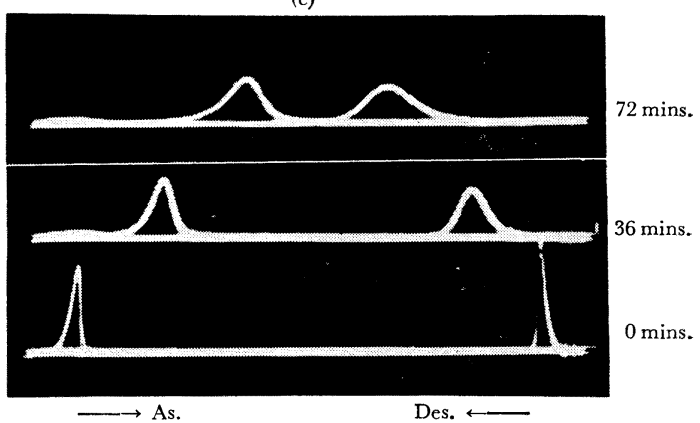

$\longrightarrow$ FIG. 4. Electrophoretic Patterns of Q-Enzyme Preparations at Various Steps of Purification.

Solvent, phosphate buffer of $\mathrm{pH} 7.8$, ionic strength, 0.1 ; electrophoresis, at $6 \mathrm{v} / \mathrm{cm}, 6 \mathrm{~mA}$ in Tiselius apparatus.

(a) Electrophoresis of enzyme IV (protein concn., $1.35 \%$, at $7^{\circ} \mathrm{C}$ )
(b) Electrophoresis of enzyme V (protein concn., $1 \%$, at $7^{\circ} \mathrm{C}$ )
(c) Electrophoresis of cnzyme VI (protein concn., $1 \%$, at $3^{\circ} \mathrm{C}$ ) 


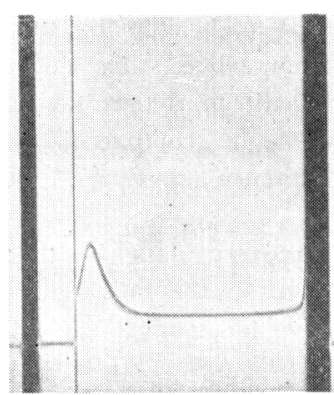

7 mins
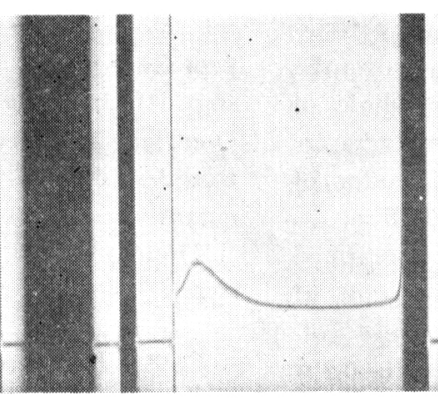

15 mins.
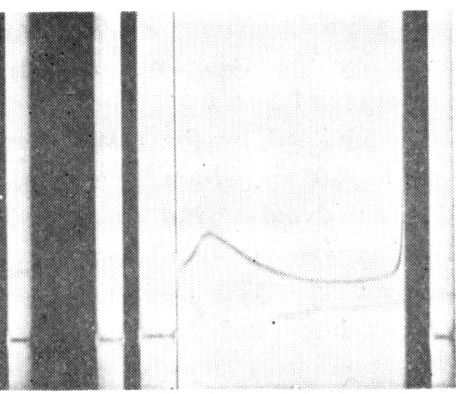

23 mins.

FIG. 5. Ultracentrifugal Patterns of Purified Q-Enzyme Preparation (EnzymeVI).

Solvent, phosphate buffer of $\mathrm{pH} 7.8$, ionic strength, 0.1 ; protein concn., $0.9 \%$; rotar speed, 56,100 r.p.m.; temparature, $5{ }^{\circ} \mathrm{C}$.

mobility of both components was calculated a: $-5.9 \times 10^{-5}$ and $-5.1 \times 10^{-5} \mathrm{~cm}^{2} \mathrm{v}^{-1} \mathrm{sec}^{-1}$, respectively.

As shown in Fig. 4c, the electrophoretic behavior of enzyme VI was considered to be nearly homogeneous. The similar results were obtained at $\mathrm{pH} 4.0$ (in acetate buffer), 6.0 and 7.0 (in phosphate buffer). As the Q-enzyme solution is unstable at $\mathrm{pH} 4.0^{11)}$, it is anticipated that the activity may be considerably lost during the experiments. However, no appreciable coagulation of the enzyme protein was observed either during the preliminary dialysis or electrophoresis at low temperature.

The electrophoretic mobility of enzyme VI was calculated as $-5.3 \times 10^{-5} \mathrm{~cm}^{2} \mathrm{v}^{-1} \mathrm{sec}^{-1}$, at $\mathrm{pH} 7.8$. Judging from these electrophoretic mobilities, it is concluded that the component with smaller mobility in Fig. $4 \mathrm{~b}$ and the component with smaller mobility than that of the highest peak in Fig. 4a, correspond to Q-enzyme.

\section{Ultracentrifugation of Enzyme VI.}

The uitracentrifugal experiment was carried out in a Spinco Model $\mathrm{E}$ analytical centrifuge at 56,100 r.p.m. Prior to the analysis, the enzyme solution was dialyzed for twenty four hours with stirring in a cold room against phosphate buffer, $\mathrm{pH} 7.8$, ionic strength 0.1 . The protein concentration of $0.9 \%$ was used. As shown in Fig. 5, the protein of enzyme VI was not completely homogeneous in ultracentrifugal analysis.

\section{Solubility of Enzyme VI.}

Enzyme VI was dissolved in $0.02 \mathrm{M}$ citrate buffer of $\mathrm{pH} 7.0$ and was dialyzed for forty eight hours against the same buffer solution at $5^{\circ} \mathrm{C}$. To $1 \mathrm{ml}$ aliquots of this solution in small centrifuge tubes were added varying amounts of ammonium sulfate solution
(pH 7.0, $40 \mathrm{~g} / 100 \mathrm{ml}$, in $0.02 \mathrm{~m}$ citrate buffer). The tube contents were mixed with a small stirring rod, allowed to stand for ten hours at $5^{\circ} \mathrm{C}$ and centrifuged (10,000 r.p.m., for ten minutes). One portion of the clear supernatant liquid was analyzed for protein by a micro-Kjeldahl method, and the other was used for determining the activity of Q-enzyme by the method described above.

The results of this solubility-activity test are graphically presented in Fig. 6. According to Fig. 6, the solubility behavior of enzyme VI against ammonium sulfate solution is presumed to indicate the homogeneity of the preparation.

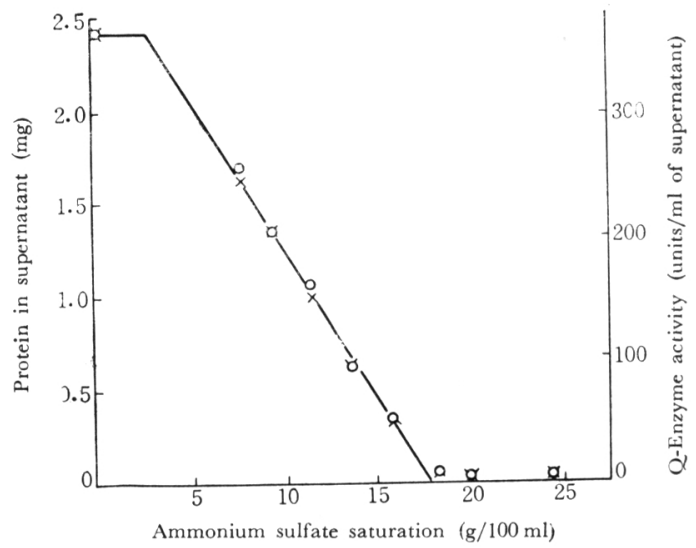

FIG. 6. Solubility Behavior of Purified Q-Enzyme Preparation (Enzyme VI).

- - - Protein in supernatant

- $\times$ Q-Enzyme activity in supernatant

Isoelectric Point of Enzyme VI.

The electrophoretic analysis of enzyme VI was conducted at $\mathrm{pH} 4.0$ (in acetate buffer), 6.0, 7.0 and 


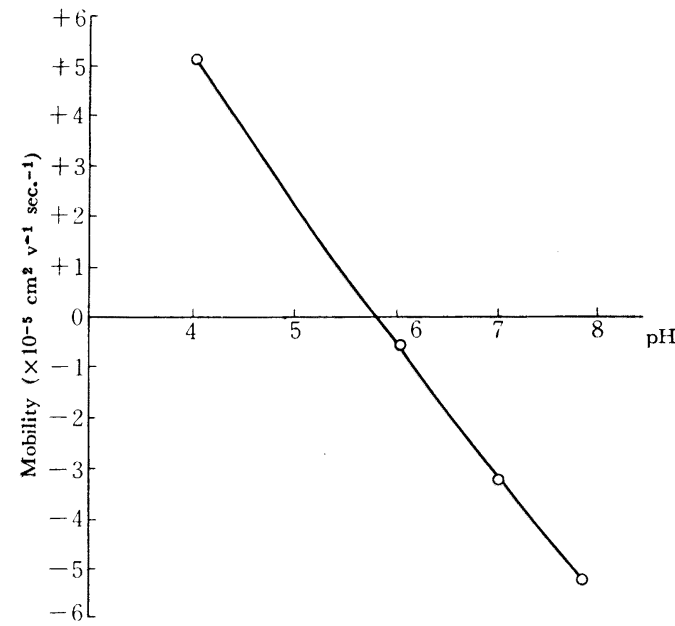

FIG. 7. Electrophoretic Mobility of Purified QEnzyme Preparation (Enzyme VI).

Solvent, acetate buffer of $\mathrm{pH} 4.0$, phosphate buffers of $\mathrm{pH} 6 . \mathrm{C}$, 7.0 and 7.8, ionic strength, 0.1 ; electrophoresis, at $6 \mathrm{~mA}, 3 \sim 5^{\circ} \mathrm{C}$ in Tiselius apparatus.

7.8 (in phosphate buffer), respectively in a Tiselius apparatus under the conditions of ionic strength 0.1 , current $6 \mathrm{~mA}, 3 \sim 5^{\circ} \mathrm{C}$.

From the results of electrophoresis at various $\mathrm{pH}$ values shown in Fig. 7 , the isoelectric point of enzyme VI is estimated to be about $\mathrm{pH} 5.8$.

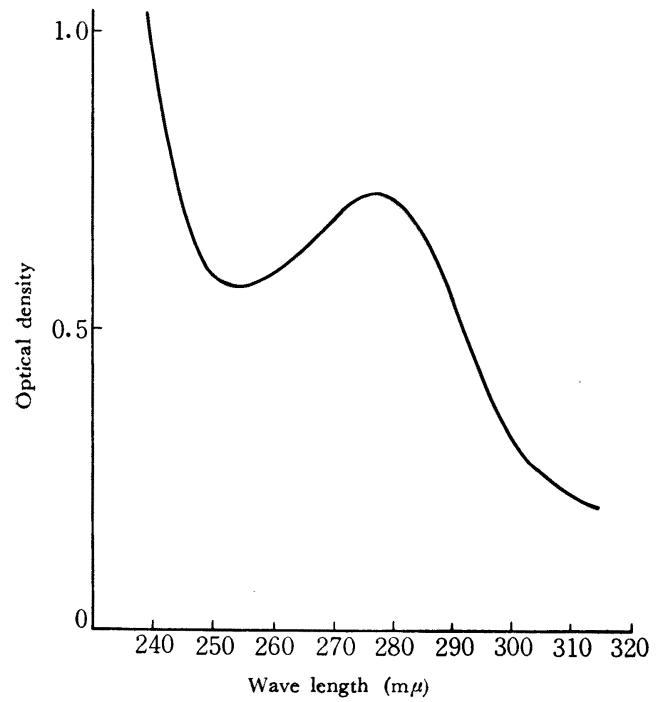

FIG. 8. Ultraviolet Absorption Spectrum of Purified Q-Enzyme Preparation (Enzyme VI).

Solvent, C.02 M citrate buffer, $\mathrm{pH}$ 7.0.
Ultraviolet Absorption Spectrum of Enzyme VI.

The ultraviolet absorption spectrum of enzyme VI was obtained by the use of a Shimazu Beckman type Model QB-50 spectrophotometer. The spectrum of enzyme VI shown in Fig. 8 indicates a typical absorption pattern of protein with the maximum absorption at $278 \mathrm{~m} \mu$.

\section{Protein Nitrogen of Enzyme VI.}

A solution of enzyme VI was dialyzed three days with stirring against distilled water at $4^{\circ} \mathrm{C}$. An aliquot from the dialyzate was precipitated with trichloroacetic acid and was used for determining the nitrogen by a micro-Kjeldahl method.

Another aliquot was used for determining ash with the usual method. From the analytical results obtained, the nitrogen content of enzyme VI protein was found to be $14.9 \%$.

\section{Action of Enzyme VI on Amylose.}

As shown in Table I, the purified Q-enzyme preparation (enzyme VI) yielded a specific activity of 155 units per $\mathrm{mg}$ protein; namely, $0.01 \mathrm{mg}$ of enzyme preparation caused a decease of $1.55 \%$ in the optical density $(655 \mathrm{~m} \mu)$ of amylose-iodine complex per minute under the optimal conditions of $\mathrm{pH} 6.7,27^{\circ} \mathrm{C}$.

The apparent velocity constant $(k)$ characterized by the first-order reaction as described in the previous paper $^{15)}$ was $1.84 \mathrm{~min}^{-1} \mathrm{mg}^{-1}$ at $25^{\circ} \mathrm{C}$. Samples of Q-enzyme rapidly converted amylose into a polysaccharide stained red with iodine.

The changes in the iodine-staining properties and

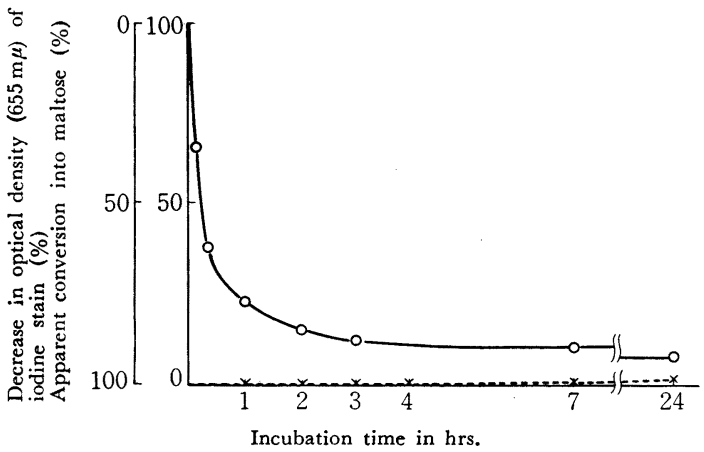

FIG. 9. Action of Purified Q-Enzyme Preparation (Enzyme VI) on Amylose.

The digest contained $5 \mathrm{ml}$ of $0.2 \%$ amylose solution, $3 \mathrm{ml}$ of citrate buffer ( $\mathrm{pH} \mathrm{6.7)}, 1 \mathrm{ml}$ of Q-enzyme solution (3.4 units) and $1 \mathrm{ml}$ of distilled water.

Temperature, $27^{\circ} \mathrm{C}$.

$$
\begin{array}{ll}
- & \text { Iodine-staining power } \\
--\times--- & \text { Reducing power as maltose }
\end{array}
$$


reducing power of the standard digest with 3.4 units of enzyme VI are shown in Fig. 9. It can be seen that the enzyme preparation causes a decrease of about $92 \%$ of the initial optical density $(655 \mathrm{~m} \mu)$ of iodine stain after twenty four hours. Thereafter, there was no more decrease of this value during the next forty eight hours. Liberation of reducing sugar was only $1.7 \%$ as maltose after twenty four hours.

\section{Enzymic Purity of Enzyme VI.}

In the ciude preparation of Q-enzyme, contamination of other enzymes concerned in synthesis and degradation of starch is found. The most persistent impurity is amylase, and its presence interferes with the measurements of activity of Q-enzyme.

Therefore, the purity of the purified Q-enzyme was examined by determining the activities of contaminating enzymes in the preparation of enzyme VI equivalent to 34 units (protein of $0.22 \mathrm{mg}$ ).

Amylase Activity: Incubation of enzyme VI with rice amylose under the optimal conditions of amylase action resulted in liberation of only $2.2 \%$ of reducing sugar as maltose after twenty four hours. The iodinestaining power of amylopectin $\beta$-limit dextrin incubated with enzyme VI under the same conditions remained constant after twenty four hours.

Maltase Activity: Enzyme VI was incubated with maltose under the optimal conditions of maltase action. The analytical result after twenty four hours showed an increase of only $1.4 \%$ of reducing sugar as glucose. Further, little liberation of glucose in paper chromatographic analysis was detected after twenty-four hours.

Isoamylase, Phosphorylase and Phosphatase Activity: No isoamylase, phosphorylase and phosphatase activity were detected in either case when enzyme VI was incubated with rice amylopectin, glucose-1-phosphate or $\beta$-glycerophosphate for twenty four hours.

From these results, it is apparent that the purified Q-enzyme preparation (enzyme VI) is nearly free from amylase, maltase, isoamylase, phosphorylase and phosphatase activity, and therefore, the color reduction of amylose stained with iodine is independent of the action of these contaminating enzymes.

\section{DISCUSSION}

Amylase bears an apparent resemblance to Q-enzyme in its action on amylose and it was a key problem in purification to prepare Q-enzyme free from amylases.
Q-Enzyme from rice seed at the milky stage was separated with considerable effectiveness from amylases, fatty acids and chlorophyll by precipitation as a lead complex according to the method of Barker et al. ${ }^{3 \sim 5}$, and by subsequent fractionation with ammonium sulfate. However, a trace amount of amylase, maltase and isoamylase was still present in the preparation obtained by the above procedure.

Further fractionation by precipitation with solvents or adsorption on starch and activated charcoal was not so effective in the attempt to remove contaminating enzymes.

Whereas, when the chromatography of these enzymes on hydroxylapatite was carried out by stepwise addition of sodium phosphate buffer, $\mathrm{pH} 6.8$ of increasing molarity, it was observed that isoamylase was not adsorbed to the hydroxylapatite column even at low concentration of $10^{-3} \mathrm{M}$, while amylase, maltase and $Q$-enzyme was adsorbed at the same concentration. Amylase and maltase was subsequently eluted at concentrations below $0.1 \mathrm{M}$, and Q-enzyme was eluted at $0.2 \mathrm{M}$. The Q-enzyme fraction obtained was nearly free from contaminating enzymes, however, it was proved to be still heterogeneous in chromatographic and electrophoretic patterns.

Furthermore, by $\mathrm{pH}$ changes of the buffer to be used during chromatography, Q-enzyme was isolated to be electrophoretically homogeneous. This preparation was also considered to be nearly homogeneous by solubility, chromatographic and enzymic analyses, but the purified preparation of Q-enzyme was not completely homogeneous so far as ultracentrifugal analysis was concerned. Whether this heterogeneity is due to the contamination with other proteins or to the association of the enzyme protein is not clear. Attempts to crystallize the purified enzyme preparation were not successful. The highly purified Q- 
enzyme preparation had a powerful activity in conversion of rice amylose into a polysac. charide stained red with iodine.

Acknowledgements. The author wishes to express his sincere thanks to Prof. F. Kurasawa of Niigata University and Prof. K. Ya- mafuji of Kyūshū University for their helpful advice and encouragement throughout the course of this work. The author is also deeply indebted to Dr. H. Sugano of Niigata University for the electrophoretic and ultracentrifugal analyses. 